\title{
STUDIES ON BIOLOGICAL ACTIVITY OF SELECTED STRAINS OF WATER BACTERIA OF GENUS PSEUDOMONAS, AEROMONAS, VIBRIO AND FLAVOBACTERIUM
}

\section{BADANIA ARTYWNOSCI BIOLOGICZNEJ WYBRANYCH SZCZEPOW}

BAKTERII WODNYCH RODZAJU

PSEUDOMONAS, AEROMONAS, VIBRIO I FLAVOBACTERIUM

From Institute of Fish Processing Technology

\begin{abstract}
An interactivity of strains of water bacteria among Pseudomonas, Aeromonas, Vibrio and Flavobacterium genus had been investigated. Proved, stimulating and antagonistic activity of the defined strains, and determined the degree of biological activity in relation to certain physical factors.
\end{abstract}

\section{INTRODUCTION}

The bacteria of Pseudomonas, Aeromonas, Vibrio and Flavobacterium genus form one of the important chains in biocenesis of sea and inland waters environment. An interactivity of these microbes and particularly the antagonistic characteristics of Pseudomonas sp. were subjected to rare investigations. W y n e and Norm a (1953) selected from seawater the strain Pseudomonas fluorescens; on agar basis the strain produced certain, not well defined, factor which inhibited the growth of some bacteria, yeast and fungus. $\mathrm{R} \circ \mathrm{th}$ (1959) selected three strains of Pseudomonas fluorescens which inhibited the growth of Bacillus cereus var. mycoides and of some saprophitic and parasite fungus. L a n d e n b e r g e r (1952) examined the antagonistic activity of Pseudomonas fluorescens on growth of $\mathrm{Ba}-$ cillus megatherium, Escherichia coli and Staphylococcus aureus. At the same time, he ascertained that formation of pigment (fluorescein) is parallel to intenseness of growth inhibition. Particularly strong antibiotic characteristics of Pseudomonas segna strain proved W a $11 \mathrm{~h} \ddot{a}$ u s e $r$ (1951) and indicated to great sensitiveness of Flavobacterium aromaticum. The examined by him Pseudomonas fluorescens straininhibited the growth of Bacillus terrestris and Bacillus petasites and stimulated the growth of Bacillus arenarius strain. K l i ng e (1959) supplemented, that only part of Pseudomo monas fluorescens strains generates the growth inhibiting factor and that only some, not numberous bacteria of this genus, are sensitive to it. Kn o r $r$, $\mathrm{H}$ a s s and K n o r - after G a a (1959) indicated that about $65 \%$ of the examined Pseudomonas fluorescens act antibiotically and this -haracte- 
ristic may be considered as constant phenomenon for the determined strains. Those authors also ascertained the antagonistic activity of these strains on some amebe species. G r ä f (1958) investigated the physico-chemical and biological characteristics of factor toxic for amebe and selected from culture of Pseudomonas fluorescens. B r u n n e r (1957) pointed out to antagonistic activity of Pseudomonas fluorescens against the strains of Aeromonas punc-. tata and he underlined the role of both species in etiology of carp sepsis.

On symbiosis among bacteria and particularly on their synergistic activity reported Nencki (1892), Burri and Stutzer (1894)-after $\mathrm{R}$ i t t e $\mathrm{r}$ (1964). Further investigations were widened and supplemented by exemples of symbiosis and metabiosis among various bacteria strains by W a 11 hä u s e r (1951/, L a nde n b e rge r (1952), R i t t e r (1964).

Aim of this work is to determine the interactivity of strains of waterbacteria of Pseudomonas, Aeromonas, Vibrio and Flavobacterium genus and an investigation of influence of the determined physico-chemical factors on antagonistic or stimulating activity of these microorganisms.

\section{MATERIAL AND METHOD}

For investigations used 22 bacterial strains of Pseudomonas, Aeromonas, Vibrio and Flavobazterium genus and their denotation presented in table 1. The strains of Aeromonas punctata Nos 1,2,3 and 4 and of Pseudomonas sp. I gr. No. 20 were selected from fresh water; Aeromonas hydrophila No.5 and Pseudomonas sp. I gr. Nos 21 and 22 were obtained fromfreshwater fish. The remaining 14 strains selected from seafish.

Used for culture of microorganisms was the meat broth and agar of 1.5 per cent and 0.7 per cent at $\mathrm{pH} 7.3$. The bacteria selected from seafish were cultured on medium with 75 per cent addition of seawater. Investigated strains were incubated in temperature of $24^{\circ} \mathrm{C}$. Numeral data of enclosed tables and diagrams present the average values of three experiments.

An interactivity of microbes was determined by linearinoculations method according to $\mathrm{H}$ e a $\mathrm{t} l \mathrm{e} \mathrm{y}$. Owing to negligeable results, the experiment was repeated according to $\mathrm{F} \mathrm{red} \mathrm{e} \mathrm{ric}$ - L e vin e method in modification of $\mathrm{K} \mathrm{j}$ e m s ( $\mathrm{K} l \mathrm{i} \mathrm{n} \mathrm{g} \mathrm{e,} \mathrm{1959).} \mathrm{The} \mathrm{zone} \mathrm{radius} \mathrm{of} \mathrm{bacterial} \mathrm{growth}$ or inhibition measured in $\mathrm{mm}$.

An influence of medium $\mathrm{pH}$ on microbes growth, on ability to generate fluoresceine, and on antagonistic or stimulating activity, examined by modified method of Frede ric q - L e vin e (1947). Concentration of hydrogen ions in medium was determined potentiometrically and the presence of pigment noted in light of Wood.

The presence of biologically active bodies in sterilized filtrates of 12 -days broth cultures, determined by dilution method of quotient $q=2$. This examinations were repeated on permanent medium of agar by "Lochtest" and the results recorded after 24 and $48 \mathrm{hrs}$.

To determine the sensivity of biologically active substance to higher temperatures, the filtrates with bacterial cultures were subjected to temperatures of $60^{\circ} \mathrm{C}$ for $30 \mathrm{~min}$. , $98^{\circ} \mathrm{C}$ for $15 \mathrm{~min}$. and $120^{\circ} \mathrm{C}$ for $20 \mathrm{~min}$. Biological activity of these filtrates was then determined by dilution method. 
Bacterial strains

\begin{tabular}{|c|c|c|c|}
\hline $\begin{array}{l}\text { Author's } \\
\text { numbering }\end{array}$ & Strains & & Denotation \\
\hline 1 & Aeromonas punctata & ED 112 & \multirow{10}{*}{$\begin{array}{l}\text { Dr A.G. Kitschel, } \\
\text { Low Temperature } \\
\text { Research Station } \\
\text { Cambridge }\end{array}$} \\
\hline 2 & Aeromonas punctata & ED 116 & \\
\hline 3 & Aeromonas punctata & ED 118 & \\
\hline 4 & Aeromonas punctate & ED 119 & \\
\hline 5 & Aeromonas hydrophila & NCMB 72 & \\
\hline 6 & Vibrio ichtyodermis & NCMB 407 & \\
\hline 7 & Vibrio sp. (luminous) & NCMB 844 & \\
\hline 8 & Pseudomonas sp. I gr. & NCMB 129 & \\
\hline 9 & Pseudomonas sp. I gr. & NCMB 406 & \\
\hline 10 & Pseudomonas sp. II gr. & NCMB 133 & \\
\hline 11 & Pseudomonas sp. II gr. & NCMB 320 & \multirow{9}{*}{$\begin{array}{l}\text { Dr M.S. Hendrie } \\
\text { Torry Research } \\
\text { Station, Aberdeen }\end{array}$} \\
\hline 12 & Pseudomonas sp.III gr. & NCMB 224 & \\
\hline 13 & Pseudomonas sp.III gr. & NCMB 322 & \\
\hline 14 & Pseudomonas sp. IV gr. & NCMB 114 & \\
\hline 15 & Pseudomonas sp. IV gr. & NCMB 130 & \\
\hline 16 & Flavobacterium sp. & NCMB 244 & \\
\hline 17 & Flavobacterium sp. & NCMB 249 & \\
\hline 18 & Flavobacterium sp. & NCMB 251 & \\
\hline 19 & Flavobacterium sp. & NCMB 257 & \\
\hline 20 & Pseudomonas sp. I gr. & $\mathrm{PZH} \quad 170$ & \multirow{3}{*}{$\begin{array}{l}\text { (PZH) State Office } \\
\text { of Hygiene Warsaw } \\
\text { author's }\end{array}$} \\
\hline 21 & Pseudomonas sp. I gr. & 101 & \\
\hline 22 & Pseudomonas sp. I gr. & 108 & \\
\hline
\end{tabular}

$E D=$ from collection of B.P. Eddy; NCMB = National Collection of Marine Bacteria; $\mathrm{PZH}=$ State Office of Hygiene; $\mathrm{Ch}=$ from author's collection.

To investigate the speed of antagonistic or stimulating activity, $0.1 \mathrm{ml}$ of 24-hr broth culture of sensitive strain added to each $10 \mathrm{ml}$ of sterilized filtrate. Further, at 30 minutes spacing, each $0.1 \mathrm{ml}$ of such filtrate was diluted in relation $1: 10$. From such dilution, $0.1 \mathrm{ml}$ was added to each $4 \mathrm{ml}$ of 0.7 per cent agar and spread on agar medium. Results were recorded after $24 \mathrm{hrs}$. 


\section{RESULTS}

Cross tests on interactivity of bacterial strains comprised 484 variants oui of which 97 , i.e. 20 per cent, proved biological activity. Antagonistic activity of examined strains appeared in 58 cases what amounts to 11.9 per cent of all positive variants; highest activity proved the strains of Pseudomonas sp. I gr.

On permanent medium, the antagonistic activity was apparent as zones free of bacterial colonies, or as zones of distinctly weaker growth. The radius after $24 \mathrm{hrs}$ ranged between 2 and $20 \mathrm{~mm}$. Along the edges of such zones, usually appeared a line of more intensive growth (Table 1,Fig. 1,2). The growth inhibiting properties were examined at the following microorganisms:

5 strains of Pseudomonas. sp. I gr. in 54 variants $=93.2 \%$

4 strains of Aeromonas sp. in 4 variants $=6.8 \%$.

The microorganisms proving antagonistic activity and the sensitive strains are presented in table 2. Particular sensitivity to activity of Pseudomonas sp. I gr. and Aeromonas sp. proved the Flavobacterium sp., Vibrio sp. and Pseudomonas, sp. III gr.

Growth stimulating activity on permanent medium was noted as zones of more intensive growth of bacterial colonie (Table 1,Fig. 3,4). This appeared in 39 cases what amounts to 8.1 per cent of all positive variants (Table 3 ). Stimulating ability of microorganisms growth proved:

5 strains of Aeromonas, SP. in 16 variants $=41.2 \%$

2 strains of Pseudornonas SP. II gr. in 6 variants $=15.3 \%$

2 strains of $\frac{\text { Pseudomonas }}{S P}$. III gr. in 9 variants $=23.1 \%$

1 strain of Pseudomonas SP. IV gr. in 5 variants $=12.8 \%$

1 strain of Vibrio sp. in 3 variants $=7.6 \%$

The sensitivity for above-mentioned microorganisms proved the strains of Aeromonas sp., Vibrio sp. and Flavobacterium sp. After 24 hrs of culture, the zones of more intensive growth attained the radius from 3.0 to $11 \mathrm{~mm}$. It maybe worth noting that, all microbes of stimulating activity stimulated the growth of Flavobacterium sp. No.18.

The growth of defined Aeromonas sp. and Flavobacterium sp. strains was simultaneously inhibited by bacteria of Pseudomonas $\mathrm{sp}$. I gr. and stimulated by strains of Aeromonas sp., Vibrio sp. and Pseudomonas sp. II, III and IV gr. Particular sensitivity proved the strain of Flavobacterium sp. No.19.

Selected for further tests were the microbes characteristic of strong antagonistic activity, viz.: Pseudomonas sp. I gr. Nos. 9, 20 and 21, the sensitive to their activity Pseudomonas sp. III gr. No. 12 and the most active growth-stimulating strains such as Pseudomonas sp. II gr. No. 11 and Aeromonas punctata No.1. The strain Aeromonas. sp. No. 4 was used as sensitive.

The investigations on influence of hydrogen ions concentration in medium on growth of bacteria proved that lowest $\mathrm{pH}$ value at which the growth appeared for examined strains amounted to 6.0 and the highest 11.5 . The colonies cultured on medium of $6.0 \mathrm{pH}$ were notnumberous, small, flat and deprived of characteristic light-grey pigmentation, while at Pseudomonas sp. I gr. appeared the traces of fluoresceine only. On medium of $6.5 \mathrm{pH}$, the growth was more intensive and at Pseudomonas sp. I gr., clearly noted the presence of green pigment. 
Antagonistic activity of Pseudomonas and Aeromonas sp. strains

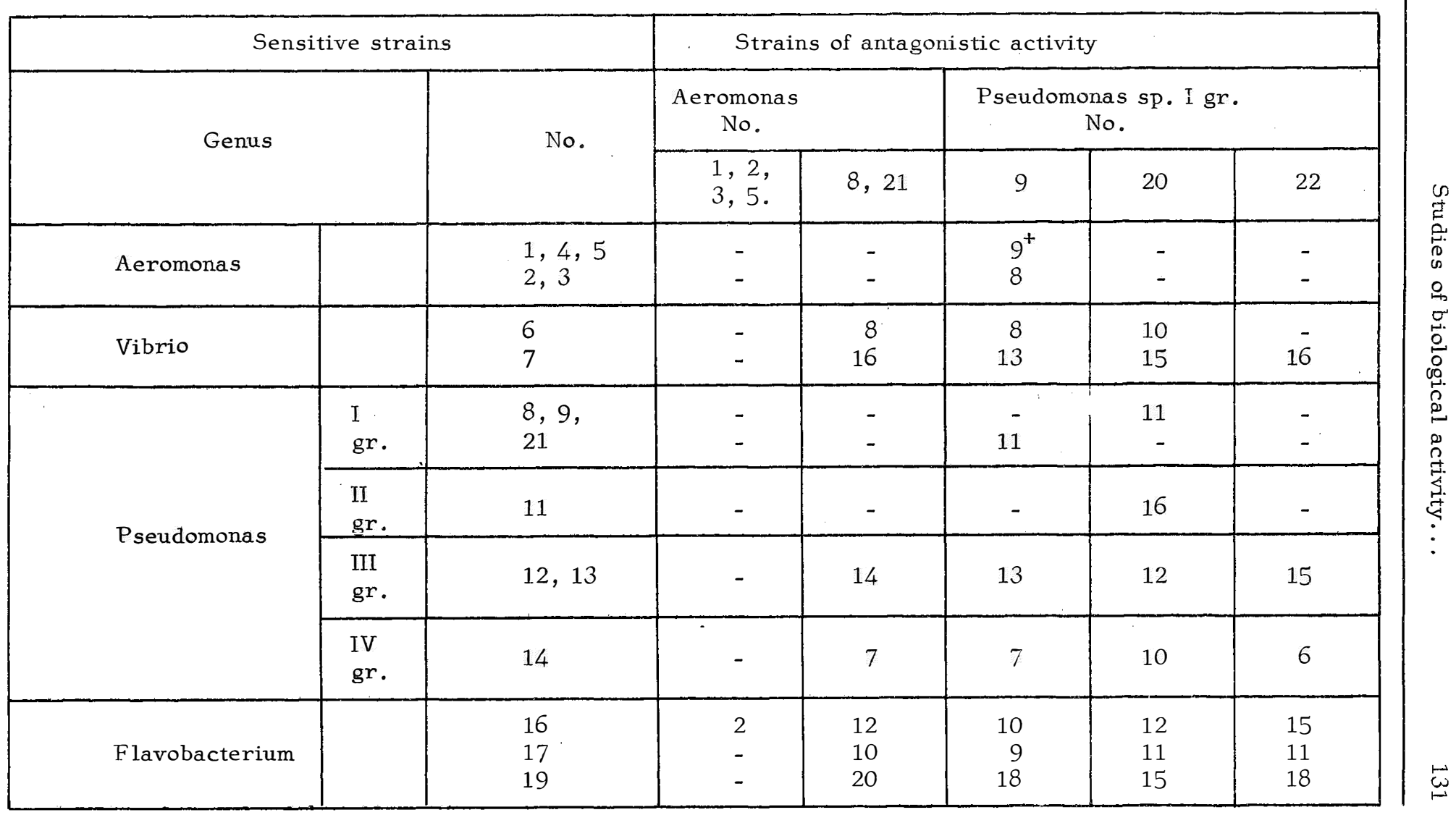




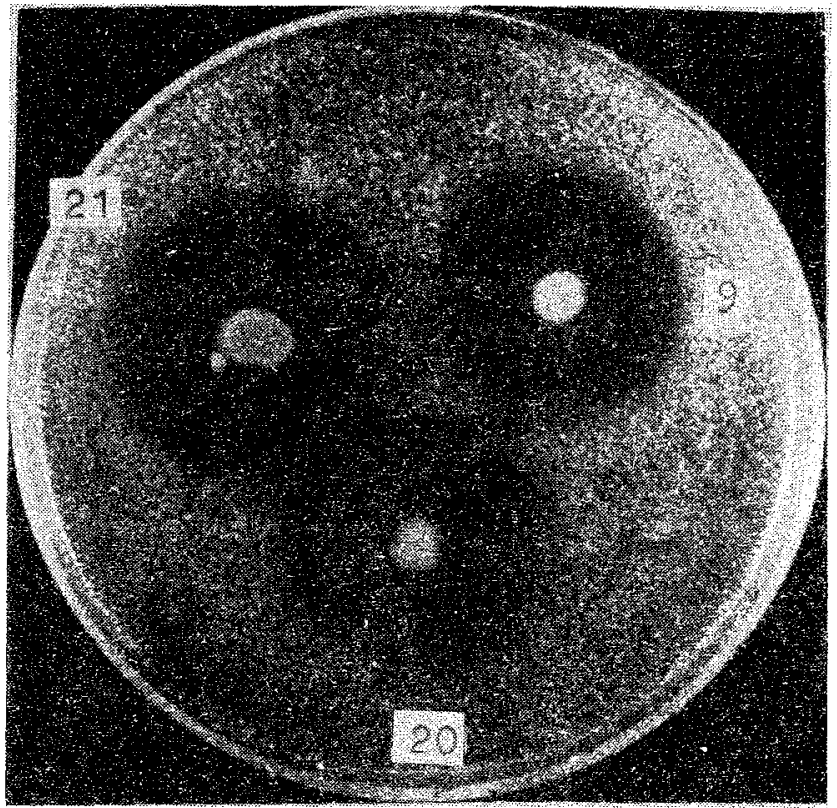

Fig.1. Antagonistic activity of Pseudomonas sp. I gr. No. 9, 20, 21. Sensitive strain: Pseudomonas sp. III gr. No.12

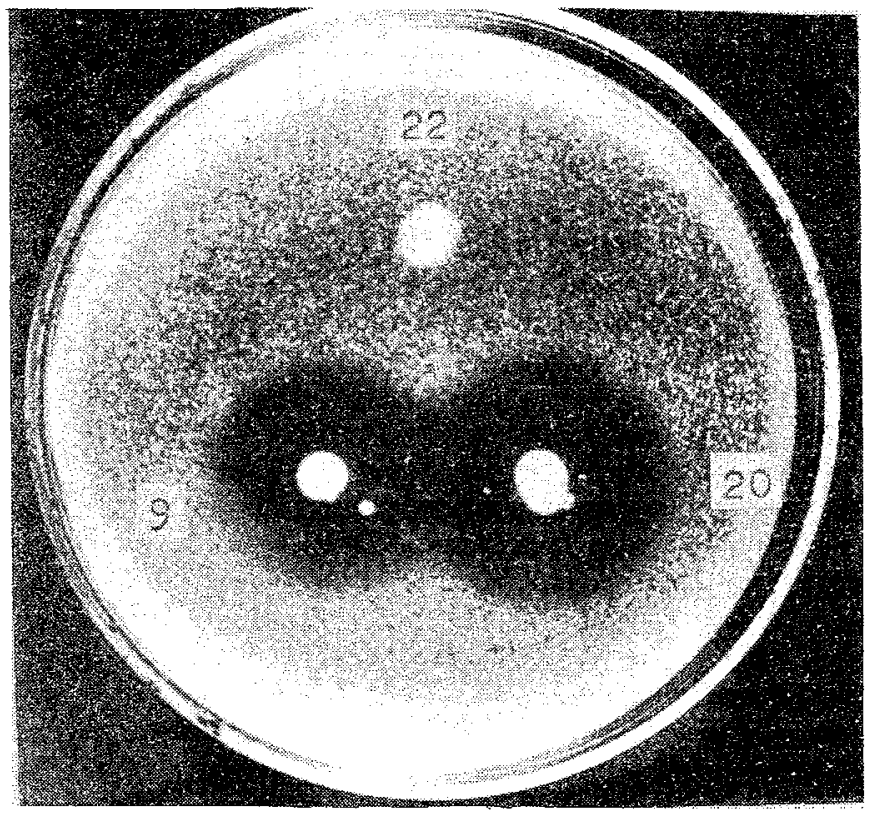

Fig.2. Antagonistic activity of Pseudomonas sp. I gr. No. 9, 20. Lack of activity: Pseudomonas I gr. No. 22. Sensitive strain: Vibrio sp. No. 6 


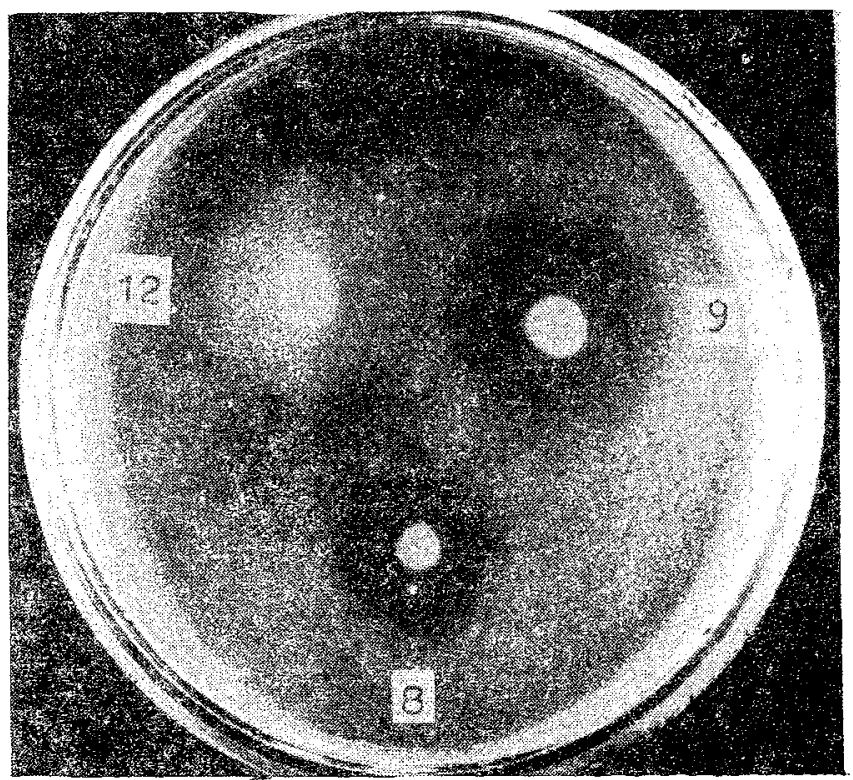

Fig.3. Stimulating activity of Pseudomonas sp. III gr. No. 12. Antagonistic activity of Pseudomonas sp. I gr. No 8, 9. Sensitive strain: Flavobacterium sp. No. 17

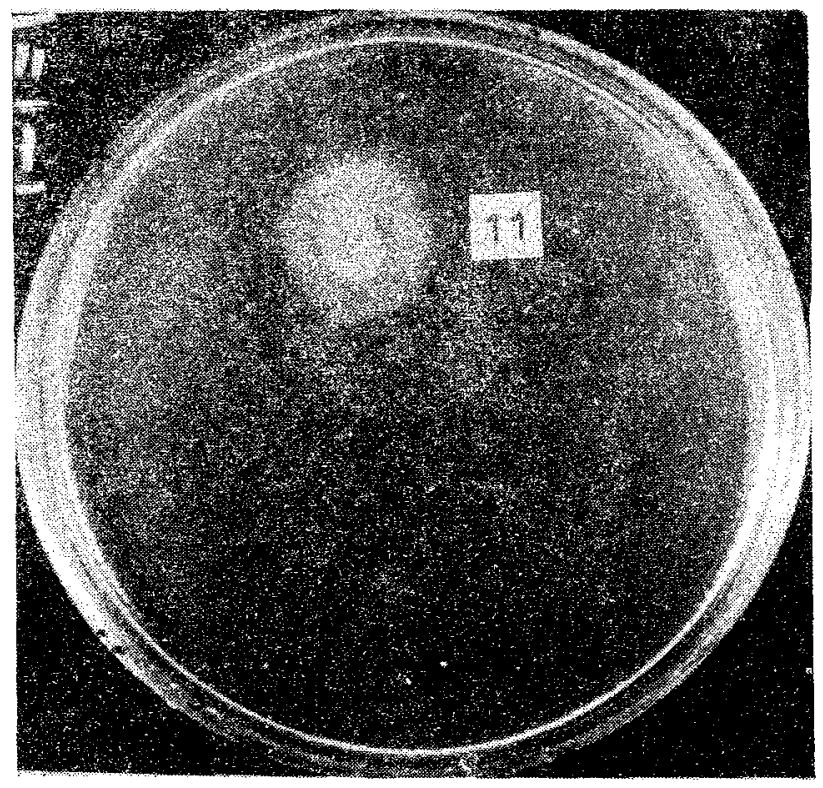

Fig.4. Stimulating activity of Pseudomonas sp. II gr. No. 11. Sensitive strain: Aeromonas sp. No. 5 
Stimulating activity

of Pseudomonas, Aeromonas and Vibrio sp. strains

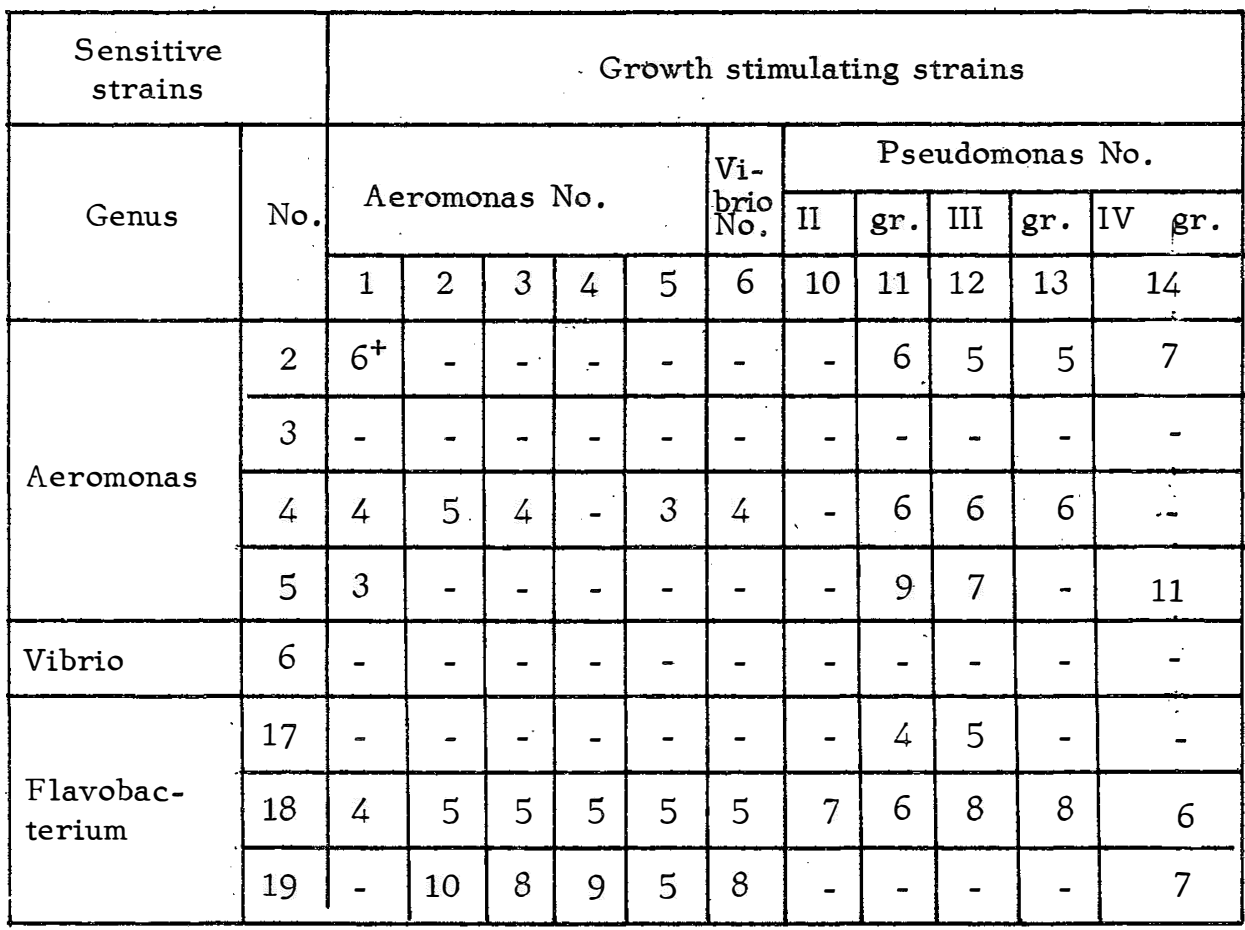

$+=$ radius of growth inhibiting zone (in $\mathrm{mm}$ )

Highest growth of colonie and of fluoresceine generation was taking place on medium of 7.0 to $8.0 \mathrm{pH}$. Gradual disappearance of fluoresceine was noted from $6.5 \mathrm{pH}$ and gradually decreasing growth of strains noted from $9.0 \mathrm{pH}$. On medium of hydrogen ions concentration of 10.0 to 11.0 were seen only the traces of bacterial colonie growth and was noted complete disappearance of pigment.

Thus, was proved the essential influence of hydrogen ions concentration in medium on antagonistic or stimulating activity of microorganisms. The results obtained indicate that maximum growth inhibition for the examined strains of Pseudomonas sp. I gr. was taking place on medium of 6.0 to 8.5 $\mathrm{pH}$, while in growth stimulating activity - on medium of 7.5 to $9.6 \mathrm{pH}$ (Fig.1).

The investigations of antagonistic properties of bacteryless filtrates of broth cultures of bacteria Pseudomonas sp. I gr. proved that the filtrate of strain No. 20 inhibited the growth of the sensitive, microbe in dilution of $1: 32$. Filtrates of strain cultures Nos 9 and 21 totally inhibited the growth in solntion of $1: 8$. Weakantibiotic activity of filtrate No. 9 and quite strong of filtrate No. 21 appeared at dilution of $1: 16$; minor activity of both these filtrates was shown in dilution 1:64 and above. 
T a b l e 4

Influence of high temperatures on antagonistic and stimulating properties of bacterial brothculture filtrates

\begin{tabular}{|c|c|c|c|c|c|c|c|c|c|c|}
\hline \multicolumn{3}{|c|}{ Filtrate } & \multicolumn{7}{|c|}{ Di $1 \mathrm{uti}$ i n s } & \multirow{2}{*}{$\begin{array}{l}\text { Sensi- } \\
\text { tive } \\
\text { strain } \\
\text { No. }\end{array}$} \\
\hline No. & ${ }_{\mathrm{O}}^{\mathrm{T}} \mathrm{Cmp}$. & $\begin{array}{l}\text { Time } \\
\text { min. }\end{array}$ & $1: 2$ & $1: 4$ & $1: 8$ & $1: 16$ & $1: 32$ & $1: 64$ & $\mathrm{~K}$ & \\
\hline 9 & $\begin{array}{r}60 \\
98 \\
120\end{array}$ & $\begin{array}{l}30 \\
15 \\
20\end{array}$ & $\begin{array}{l}- \\
- \\
-\end{array}$ & $\begin{array}{l}- \\
- \\
-\end{array}$ & $\begin{array}{l} \pm \\
+ \\
\pm\end{array}$ & $\begin{array}{l}++ \\
++ \\
+\end{array}$ & $\begin{array}{l}+++ \\
+++ \\
++\end{array}$ & $\begin{array}{l}+++ \\
+++ \\
+++\end{array}$ & $\begin{array}{l}+++ \\
+++ \\
+++\end{array}$ & \\
\hline 20 & $\begin{array}{r}60 \\
98 \\
120\end{array}$ & $\begin{array}{l}30 \\
15 \\
20\end{array}$ & $\begin{array}{l}- \\
- \\
-\end{array}$ & $\begin{array}{l}- \\
- \\
-\end{array}$ & $\begin{array}{l}- \\
- \\
-\end{array}$ & $\begin{array}{l}- \\
+ \\
+\end{array}$ & $\begin{array}{l}+++ \\
+++ \\
++\end{array}$ & $\begin{array}{l}+++ \\
+++ \\
+++\end{array}$ & $\begin{array}{l}+++ \\
+++ \\
+++\end{array}$ & 12 \\
\hline 21 & $\begin{array}{r}60 \\
98 \\
120\end{array}$ & $\begin{array}{l}30 \\
15 \\
20\end{array}$ & $\begin{array}{l}- \\
- \\
-\end{array}$ & $\begin{array}{l}- \\
- \\
-\end{array}$ & $\begin{array}{l}- \\
- \\
-\end{array}$ & $\begin{array}{l}- \\
- \\
+\end{array}$ & $\begin{array}{l}++ \\
++ \\
++\end{array}$ & $\begin{array}{l}+++ \\
+++ \\
+++\end{array}$ & $\begin{array}{l}+++ \\
+++ \\
+++\end{array}$ & \\
\hline 1 & $\begin{array}{r}60 \\
98 \\
120\end{array}$ & $\begin{array}{l}30 \\
15 \\
20\end{array}$ & $\begin{array}{l}S \\
S \\
S\end{array}$ & $\begin{array}{c}S \\
S \\
+++\end{array}$ & $\begin{array}{c}+++ \\
+++ \\
+++\end{array}$ & $\begin{array}{l}+++ \\
+++ \\
+++\end{array}$ & $\begin{array}{l}+++ \\
+++ \\
+++\end{array}$ & $\begin{array}{l}+++ \\
+++ \\
+++\end{array}$ & $\begin{array}{l}+++ \\
+++ \\
+++\end{array}$ & \\
\hline 11 & $\begin{array}{r}60 \\
98 \\
120\end{array}$ & $\begin{array}{l}30 \\
15 \\
20\end{array}$ & $\begin{array}{l}s \\
s \\
s\end{array}$ & $\begin{array}{l}+++ \\
+++ \\
+++\end{array}$ & $\begin{array}{l}+++ \\
+++ \\
+++\end{array}$ & $\begin{array}{l}+++ \\
+++ \\
+++\end{array}$ & $\begin{array}{l}+++ \\
+++ \\
+++\end{array}$ & $\begin{array}{l}+++ \\
+++ \\
+++\end{array}$ & $\begin{array}{l}+++ \\
+++ \\
+++\end{array}$ & 4 \\
\hline
\end{tabular}

- no growth; I growth traces; + weak; ++ mean; +++ strong growth; S stimulating activity.

Stimulating activity of sterile filtrates of broth cultures was distinct, however, the spectrum of activity was not very high. The strain filtrate of Aeromonas punctata No.1 stimulated the growth of Aeromonas punctata No.4 in dilution of $1: 4$, while the filtrate of Pseudomonas sp. II gr. No. 11 stimulated the growth of the same strain sensitive in dilution of $1: 2$. The intenseness of biological activity of filtrate on permanent medium was distinctly weaker in comparison with activity of direct agar cultures of the respective strains.

The investigation results on sensitiveness to higher temperatures of biologically active bodies comprised in filtrates, are presented in table 4 . It 


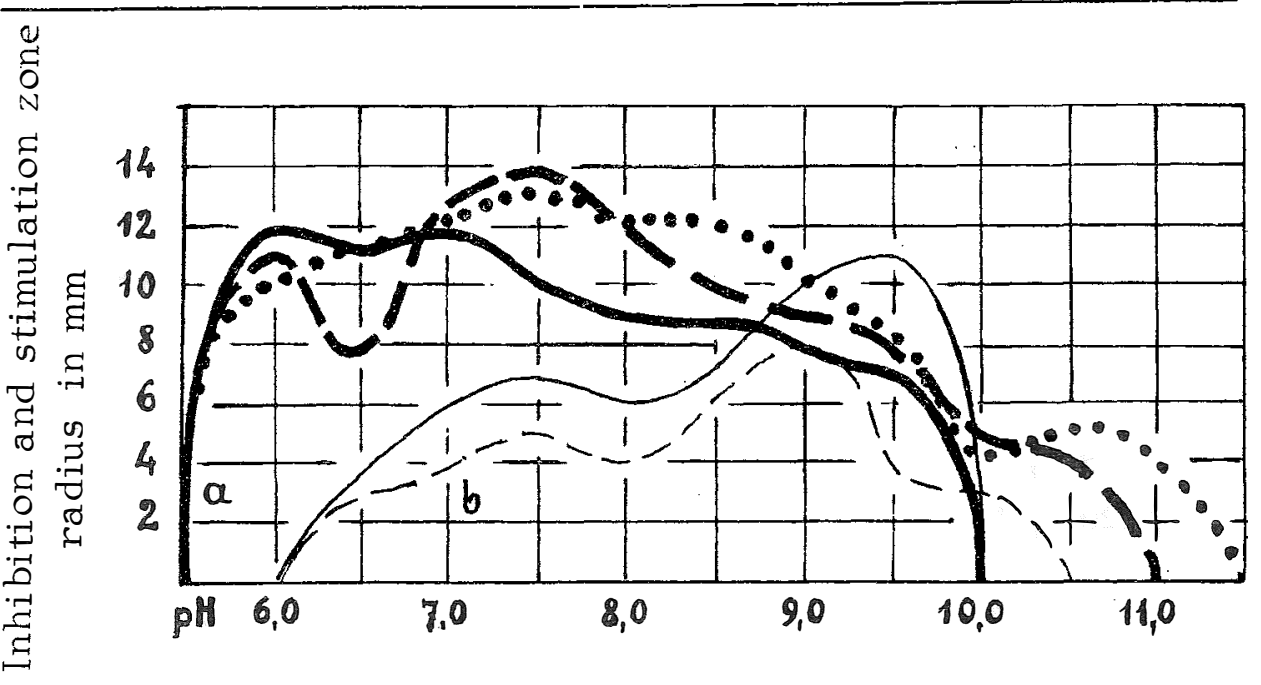

Fig.5. Influence of medium $\mathrm{pH}$ on activity of Pseudomonas and Aeromonas species strains

a. antagonistic activity

Pseudomonas sp. I gr. No. 9

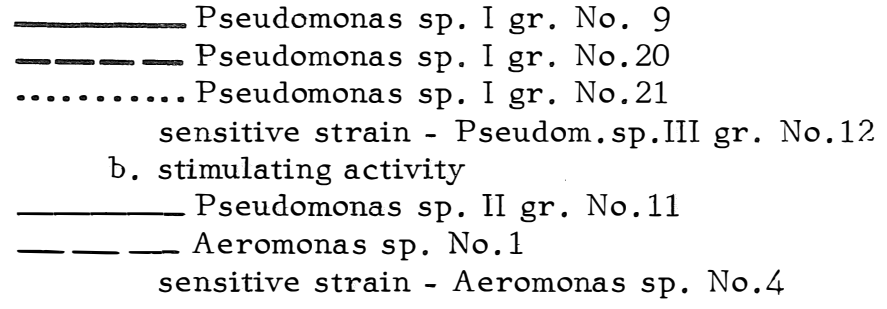

ascertained, that only minor decrease of antibiotic and stimulating activity was obtained by heating to temperature of $60^{\circ} \mathrm{C}$, by boiling under $98^{\circ} \mathrm{C}$ and by autoclaving under $120^{\circ} \mathrm{C}$.

\section{DISCUSSION}

The sea environment and its dynamic nature is characteristic for many interconnected factors which influence the quantity and the composition of species of bacterial population. Therefore, it is frequently difficult to define any influence seperately for each of these factors. The variations of day and season, those deriving from geographical latitude, depth and from serie of other parameters, principally complicate the problem. For these reasons, the laboratory investigations with participation of microorganisms of sea origin, can not ensure many important moments which condition the maximum growth and full activity of microorganisms.

Performed investigations proved an interactivity of the determined waterbacteria strains of Pseudomonas, Aeromonas, Vibrio, and Flavobacterium. relating to their antagonistic and growth stimulating activity. Antagonistic properties of strains were seen as growth inhibiting zones of sensitive 
bacteria; width of these zones was directly proportional to grade of activity . Towards antagonistic activity of strains of Pseudomonas. SP. I gr. (Pseudomonas fluorescens) indicated already $G \mathrm{r}$ a f (1958), $\mathrm{L}$ a $\mathrm{nd}$ e $\mathrm{n} \mathrm{b} \mathrm{e} \mathrm{r-}$ ger (1952), Guthrie et al. (1965), Krasilnikova (1961), Ritter (1964), Brunner (1957) and K linge (1959). From accessible literature, no data can be found on direct stimulating activity within the microbes of genus Pseudomonas, Aeromonas, Vibrio and Flavobacterium. In our investigations is proved that certain growth stimulating properties possess some strains of Pseudomonas sp: II, III and IV gr., Vi-. brio sp. and Aeromonas sp. Particular sensitivity to stimulating activity proved the Flavobacterium sp. and certain Aeromonas. $\mathrm{sp}$. It is peculiar, that none of strains of Pseudomonas sp. I gr. was sensitive to stimulating activity .

Great probability exists that biologically active substances generated by bacterial cells during their lifes are emitted into environment, or are released from dead-cells under lysis-process, diffuse into agar medium and exhibit an activity appart from their bacterialcultures. The presence of biologically active bodies in sterile filtrates of broth culture of strains examined supports such thesis. An activity of these filtrates was, however, distinctly weaker from values obtained from direct culture of correspondingstrains on permanent medium. Probably, part of active bodies infiltrates was absorbed by bacteriological filters. Further investigations are to be performed to determine the origin and nature of active bodies.

The strains used in our investigations were growing on permanent medium of $\mathrm{pH}$ from 6 to 11 . Highest antibiotic activity proved the strains of Pseudomonas sp. I gr. in acid, neutral or in slightly alcalic environment $\overline{\mathrm{pH} 6.0}$. 8.0). Maximum of stimulating activities proved the strains of Aeromonas sp.

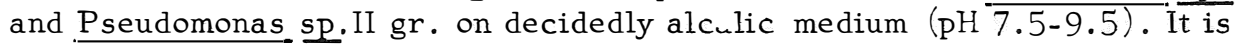
apparent then, that concentration of hydrogen ions in environment presents an essential factor in shaping the biological activity of microorganisms.

Obtained results indicate that fluoresceine is not the only factor responsible for antibiotic properties of strains of Pseudomonas $\mathrm{sp}$. I gr. This is supported by fact, that in spite of pigment appearance only in traceable quantities on medium of $6.0 \mathrm{pH}$, the growth-inhibiting intenseness was distinct.

From works of $\mathrm{L}$ a n d e $\mathrm{n} \mathrm{be} \mathrm{rge} r$ (1952) and K ling e (1959) appears that, growth-stimulating and inhibiting factors generated by bacteria, are of thermolabile nature. Our own results indicate to thermolabile nature of biologically active substances. By subjecting the filtrates to high temperatures $\left(120^{\circ} \mathrm{C}\right)$ was eliminated the probability of bacteriophages acting as growth-inhibiting actor.

Among the microorganisms in genus Pseudomonas, Aeromonas,Vibrio and Flavobacterium, which dominate among the bacteria of seu environment appear the strains which are the natural antagonists, or the strains living in symbiosis like in other environments. The antagonistic and stimulating activity on determined water microorganisms, which is proved in our work, may contribute towards wider and better recognition of their biological properties. 


\section{CONCLUSIONS}

1. Among the water bacteria of genus Pseudomonas, Aeromonas, Vibirio and Flavobacterium, are appearing the strains of antagonistic and stimulating properties. An ability for generation of active bodies and the sensitiveness proved certain defined bacterial strains only.

2. Antagonistic activity proved the strains Pseudomonas sp. I gr., while stimulating activity - Pseudomonas sp. II, III and IV gr., Aeromonas.sp. and Vibrio sp. Sterile filtrates of broth culture of defined strains also proved the antibiotic and stimulating activity.

3. The concentration of hydrogen ions in environment presents a vital factor in shaping the biological activity of microorganisms. Highest antibiotic activity was appearing on medium of $6.0-8.0 \mathrm{pH}$, while stimulating activity - on 7.5-9.5 $\mathrm{pH}$ medium.

4. The bodies responsible for antagonistic and stimulating activity proved to be of thermolabile nature.

\section{REFERENCES}

B ru nn e r G., 1957: Eine Beobachtung über Antibiose bei Pseudomonas Bakterien-Arch. Mikrobiol., 25, 369.

B u r z y ńs ka H., 1964: Metoda wykrywania i identyfikacji pałeczek $z$ grupy Pseudomonas - Achromobacter i grup pokrewnych. [Bacillus detection and identification of Pseudomonas - Achromobacter and of relative groups]. Roczn. PZH, 15, 2, 171.

Frederic q P. and L e vine M., 1947: Antibiotic interrelationships among the enteric group of bacteria. J. Bact., 54, 785.

Grä f W., 1958: Üeber Gewinnungund Beschaffenheit protostatisch-protocider Stoffe aus Kulturen von Pseudomonas fluorescens. - Arch. Hyg. (Berl. ), 142, 267.

Guthrie R., Cooper B., Ferguson J., Allen H., 1965: Interaction between Escherichia coli and Pseudomonas aeruginosa in mixed cultures.-Canad. J.Microbiol., 11, 6, 947.

K l i n g e K., 1959: Pseudomonas fluorescens ein Wasser- und Bodenkeim. II. Antibiozische Wirkungen unter Ps.fluorescens -Stämmen,-Arch。 Mikrobiol., 33, 406.

K r a s i l n i k o va E., 1961: Obantibioticzeskich swoistvach mikroorganizmov widelennich is razlicznich głubin Mirnogo Okeana. Mikrobiołogia, $30,4,651$. (Antibiotic properties of microorganisms from various depths of ocean waters).

L a n d e n.b e r g e r R., 1952: Hemm- und Wuchsstoffe bei Pseudomonas fluorescens. $-Z$. Naturforsch., 7b, 11, 630.

R i t t e r P., 1964: Antibiose und Symbiose bei den ${ }^{-}$Mikroorganismem und ihre Auswirkungen in der milchwirtschaftlichen Technik.-Kieler Milchwirtsch. Forschungsbericht, 16, 6, 439. 
R ot h G., 1959: Ueber antibiotische Wirkungen bon drei Pseudomonasarten auf Wachstum und Mycelbildung yon samenbegleitenden Pilzen sowie Bacillus cereus var. mycoides.-Arch. Mikrobiol., 33, 378.

W a $11 \mathrm{~h}$ a u s e r K., 1951: Untersuchungen über das antagonistische Verhalten von Mikroorganismem am natürlichen Standort.-Arch. Mikrobiol., $16,237$.

W y n e E., Nor m a n J., 1953: On the concept of "direct antagonism" in bacteria.-J. Infect. Diseases, 93, 243.

\section{BADANIA AKTYWNOŚCI BIOLOGICZNEJ WYBRANYCH SZCZEPÓW BAKTERII WODNYCH RODZAJU PSEUDOMONAS, AEROMONAS, VIBRIO I FLAVOBACTERIUM}

\section{Streszczenie}

Badano wzajemne oddziaływanie 22 szczepów bakterii wodnych rodzaju Pseudomonas, Aeromonas, Vibrio i Flavobacterium. W krzyżowych badaniach, ná 484 kombinacji, właściwości hamowania lub pobudzania wzrostu wykazało 20\%, w tym aktywność antagonistyczną przejawiało 11,5\% a stymulacyjną $8,1 \%$ kombinacji dodatnich. Stwierdzono, że zdolność do produkcji ciał czynnych i wrażliwość na te ciała posiadały tylko określone szczepy bakteryjne. Aktywność antagonistyczną wykazały głównie szçzepy Pseudomonas sp. I gr., zaś aktywność stymulacyjną Pseudomonas II, III i IV gr., Aeromonas sp. oraz Vibrio sp. Znaczną wrażliwość na działanie antygonistyczne i stymulacyjne przejawiały określone szczepy Flavobacterium sp.i Aeromonas sp. Wykazano ponadto, że jałowe przesącze bulionowych hodowli szczepów aktywnych biologicznie posiadały również właściwości hamowania wzrostu szczepów wrażliwych nawet w rozcieńczeniu 1:34, a także pobudzania wzrostu w rozcieńczeniu $1: 4$.

$Z$ przeprowadzonych badań wynika, że istotnym czynnikiem mającym wpływ na stopień aktywności szczepów bakteryjnych jest stężenie jonów wodorowych środowiska. Optymalna bowiem aktywność antagonistyczna występowała na podłożach o $\mathrm{pH}$ 6,0 do 8,0 zaś stymulacyjna przy $\mathrm{pH}$ 7,5 do 9,5. Charakterystycznym jest, że ciała odpowiedzialne za aktywność biologiczną badanych szczepów posiadają ciepłostały charakter.

ИССЛЕДОВАНИЯ БИОЛОГИЧЕСКОЙ АКТИВНОСТИ ОТДЕЈБНЫХХ КУЛЬТУР ВОДНЫХ БАКТЕРЙ̈Y РОДА PSUDOMONAS, AEROMONAS, VIBRIO

II FLAVOBACTERIUM

$$
P \text { e } 35 \mathrm{Me}
$$

Исследовано взаимодействие 22 культур водных бактерий рода Pseudomonas, Aeromonas, Vibrio и Flavobacterium. В перенрёстных исследова- 
ниях в 484 комбинациях способностью торножения или воби́ужднния роста характеризовґлось 20\%, из которых антагонистическую антивность іроявляло $11,5 \%$ а стимулирующую- 8,1\% полощительных юомбпнаций

Установлено, что способность к производству активнык тел и чувствительность на эти тела имели тольно определённые бактериальные культуры. Антагонистическую антивность проявили главным образом культуры Pseudomonas sp. I группы, стимулирующую же активность - Pseudomonas II, III и IV групп, Aeromonas sp•,а аткже Vibrio sp. Змаетную чувствительнасть на антагонистическое и стимулируюее действие проявляли определённые культуры Flavobacterium sp. и Aeromonas sp.Кроме того установлено, -что стерильные фильтраты бульонного разведения биологически активных культур имели танже способность торможения роста культур, чувствительных даже при разбавлении I:34, а также возбуждения роста прй разбавлении $I: 4$.

Из проведенных исследований следует, что существенным фоктором, имеющим влияние на степень активности бактериальных культур, является нонценітация водородных ионов среды, так как оптимальная антагонистическая активность наблюдалась на субстратах с рH 6,0 - 8,0, а стимулирующая при рН 7,5 - 9,5. Характерным является то, что тела, ответсвтенные за биологическую активность исследуемых культур, имеют постоянный термическиї харажтер.

\section{Address :}

Received 17.IX. 1971

Doc.dr h. Andrzej. Chodyniecki

Instytut Technologii Przetwórstwa A R

Rybnego

Szczecin, ul. Kazimierza Królewicza 4

Polska - Poland 